\title{
Structural and compositional features of high- rise buildings: experimental design in Yekaterinburg
}

\author{
Yulia Yankovskaya ${ }^{1 *}$, Yuriy Lobanov ${ }^{1}$, and Vladimir Temnov ${ }^{1}$ \\ ${ }^{1}$ Saint Petersburg State University of Architecture and Civil Engineering, Department of Urban \\ Planning, Vtoraya Krasnoarmeyskaya str. 4, Saint Petersburg, 190005, Russia
}

\begin{abstract}
The study looks at the specifics of high-rise development in Yekaterinburg. High-rise buildings are considered in the context of their historical development, structural features, compositional and imaginative design techniques. Experience of Yekaterinburg architects in experimental design is considered and analyzed. Main issues and prospects of high-rise development within the Yekaterinburg structure are studied. The most interesting and significant conceptual approaches to the structural and compositional arrangement of high-rise buildings are discussed.
\end{abstract}

\section{Introduction}

Yekaterinburg, as most of large and largest cities of Russia, transforms and acquires its new image and silhouette due to gradual high-rise development. This aspect requires timely analysis. Moreover, prospects of architectural development of the capital of the Urals shall be defined. Historically, Yekaterinburg was one of the leaders for the implementation of advanced architectural concepts developed by constructivist architects and the harbinger of avant-garde architecture in 1920-1930. Progressive trends related to intensified construction of high-rise and super-high-rise buildings, which penetrated many cities of Europe and Asia in the late 20th - early 21st centuries, affected Yekaterinburg as well. Switching of Russia to the market economy also contributed to the intensification of this process. High-rise buildings appeared in Yekaterinburg a little bit later and became a determining factor for the city development and silhouette only in the 2000s.

High-rise construction projects and the emergence of super-high-rise buildings in the 2000 s posed a number of challenging issues craving resolution, i.e. new ways for the optimum introduction of high-rise buildings into the existing structure of the historical city located in unfavorable climatic conditions of the Urals region.

Historical aspects, trends and prospects of high-rise development in Yekaterinburg, conceptual issues of the formation of high-rise buildings meeting modern ideas of the comfortable architectural environment.

\footnotetext{
${ }^{1}$ Corresponding author: jul3203226@gmail.com
} 


\section{Materials and methods}

The methodological basis of the study is a set of historical, typological, compositionalartistic approaches. To identify the origins of the formation of high-rise dominants in the city structure, the historical-genetic approach was applied. To assess existing and designed objects, the simplified typological method was used, based on two major classifications: by height and complexity of the building structure. Analysis of the role of high-rise buildings in the city structure in various historic periods and evaluation of promising trends of their formation are carried out on the basis of the compositional-artistic approach. The author conducted on-site investigations of high-rise buildings in Yekaterinburg, both constructed and under construction. The author also acted as a supervisor of research works, competitive and experimental design of high-rise buildings at the Department of Architecture [1, 2, 3, 4] of the Ural State University of Architecture and Art.

Main architectural and typological classifications used in the study are as follows: classification by height and complexity of the building structure. A summarized classification of buildings by height (with account for the interaction of the latest national and international theory and practice) is as follows $[5,6]$ :

- low-altitude (low-rise) buildings - up to $10 \mathrm{~m}$ (1-3 floors);

- medium-altitude (multi-story) buildings - from 10 to $30 \mathrm{~m}$ (4-9 floors);

- buildings of excess height - from 30 to $75 \mathrm{~m}$ (10-24 floors);

- high-rise buildings - from 75 to $200 \mathrm{~m}$;

- super-high-rise buildings - more than $200 \mathrm{~m}$.

Super-high-rise development can be classified by six categories:

Category 1: buildings and structures from 200 to $400 \mathrm{~m}$ (Aqua, Chicago)

Category 2: buildings from 400 to $600 \mathrm{~m}$ (Okhta Center in Saint Petersburg, design)

Category 3: buildings from 600 to $700 \mathrm{~m}$ (Chicago Spire, design)

Category 4: buildings from 700 to $800 \mathrm{~m}$ (Anara Tower, design)

Category 5: buildings from 800 to $900 \mathrm{~m}$ (Burj Khalifa in Dubai);

Category 6: buildings from 900 to $1000 \mathrm{~m}$ and more (Kingdom Tower in Saudi Arabia).

Based on this classification, we can get a good idea of the significance of an object in the high-rise development system.

Another classification used in the study describes the degree of simplicity and complexity of the structural solution in a plan and the sectional view of a building. This classification is based on the analysis of global experience in high-rise construction and national typological developments $[7,8,9]$. The classification is based on the following variables:

- rigidity/flexibility of space planning (free plan / rigid cell system / combined system / atrium system); presence/absence of central prominent structural/communicational nodes;

- penetrability / limited penetrability of vertical enclosing structures / self-sufficiency of the building enclosure;

- rigid vertical floor-by-floor separation / presence of vertical atriums.

The following summarized classification of structural features of vertically developed buildings can be presented based on those variables:

- medium-altitude buildings with a rigid planning structure;

- buildings of excess height and a rigid or flexible planning structure;

- high-rise buildings with a uniformly distributed vertical floor-by-floor structure

("buildings-stack-like structures") with a free or combined planning structure;

- high-rise buildings with vertical atriums and a free or combined planning structure;

- high-rise buildings with vertical atriums (vertical-block buildings), a free or combined planning structure and a relatively autonomous enclosure - "building - vertical city";

- super-high-rise buildings-stack-like structures with a combined planning structure;

- $\quad$ super high-rise vertical-block buildings with a combined planning structure. 


\section{Results}

\subsection{Historical and architectural aspect of high-rise development in Yekaterinburg}

Stage 1 ("pre-revolutionary" stage) - the first half of the 18th century - the beginning of the 20th century. In general, this period is characterized by low-rise individual development. Plant management buildings and temples served as compositional dominants. Only church bell towers of those days can be classified as objects of "high-rise development". The most significant high-rise dominants of that period are as follows: the Cathedral of St. Catherine the Great Martyr (1723, height $=58 \mathrm{~m}$, architect Johann Miller); Church of the Ascension (1801, height $=63.4$ m, architects: M. P. Malakhov, K. G. Tursky, N. Shulayev); the Great Zlatoust Church (1876, height $=77.2 \mathrm{~m}$, architect: V. E. Morgan). Such large-scale buildings as the Alexander Nevsky Cathedral (1848) and the Holy Trinity Cathedral (1839) are worth mentioning as well [10]. A complex of high-rise architectural dominants, combined by a system of visual connections, formed in the city during that period. Dominants located on the same visual axis formed systems of panoramic and spatial complexes determining silhouette characteristics of Yekaterinburg and the system of subordinated architectural area of residential and industrial buildings. Dominants of temples formed the basis for city silhouette expressiveness.

Stage 2 ("post-revolutionary" stage). 1920s-1930s. It was the period of industrialization and constructivism in the city architecture. In 1924, Yekaterinburg was renamed Sverdlovsk and acquired a new altitude range. According to the classification, in general, those were medium-altitude buildings and buildings of excess height. Constructivist buildings and complexes appeared, which largely determined the modern architectural and historical environment and cultural significance of the city: the Uralmash socialist city, Vtuzgorodok, OMM ensemble, residential complexes on Malysheva street and Lenina street, the Dinamo stadium, and a unique complex — the Chekist Town with a high-rise building of the Iset hotel $(1933$, height $=40 \mathrm{~m}$, architects: I. P. Antonov, A. M. Tumbasov, V. D. Sokolov). The aesthetic nature of the city changed. A new altitude range of Yekaterinburg-Sverdlovsk was set. A significant number of 4-6-story buildings and 811 -story dominants appeared, such as the Central Post Office, Unipromed Institute (at the corner of Lenina street and Tolmacheva street), NKVD House $(1932$, height $=34 \mathrm{~m}$, architects: I. P. Antonov, V. D. Sokolov) [10]. Most temples determining the silhouette of the pre-revolutionary city were demolished during that period. New constructivist dominants became high-rise landmarks. A significant project of a 140-m skyscraper - a high-rise dominant in the building complex "House of Industry" - also related to the period of industrialization. Its construction started in 1931, and in 1935 it was canceled.

Stage 3 ("late Soviet" stage) - the second half of the 20th century. Only several buildings of excess height were built in Sverdlovsk in the 1940s-1960s. The Building of the Sverdlovsk City Council of People's Deputies (1930-1954, height $=61 \mathrm{~m}$, architects: G. A. Golubev, M. V. Reischer), and 10-story building of the Rubin plant (1964, architect: P. D. Dyomintsev) were reconstructed [10]. In the mid-1960s, the large-scale construction of 9-story brick (and later - panel) buildings of standard series started in Sverdlovsk. In the 1970s-1990s, a television tower $(1991$, height $=220 \mathrm{~m}$, designed by the State Union Designing Institute) became the main vertical dominant of the city. Standard 16-story buildings started to define the high-rise appearance of residential areas. Tall buildings of the constructivism period and the surviving Church of Ascension remain the dominants in that period. Three objects continued to dominate in the center of the city: the building of the Rubin plant (architect: P. Dyomintsev), grand building of the City Executive Committee with a spire (architects: G. Golubev, M. V. Reischer) and NKVD House (architects: I. 
Antonov and V. Sokolov). In 1981, in the southern part of Sverdlovsk, near the bus terminal, an impressive building of the computing center, designed by architect A. Astashkin, was constructed. In the late 1970s, the construction of high-rise buildings began in the city. In 1975-1981, a 23-story high-rise building of the House of the Soviets (height $=89 \mathrm{~m})$ was constructed at the initiative of Boris Yeltsin, the first secretary of the Sverdlovsk Regional Committee of the Communist Party of the Soviet Union at that period. For two decades, this building was the highest object in the city. The overall height of the large-scale urban development significantly increased during that period. However, the high-rise dominants remained within the limits set by pre-revolutionary church bell towers.

Stage 4 ("post-soviet") - the first decades of the 21 st century. Generally, only this period is associated with the large-scale construction of high-rise buildings. New economic relations and changes in the social format of Russia became the basis for numerous social and cultural changes, including the widespread use of high-rise buildings in the structure of previously established cities. During that period, Yekaterinburg (renamed back in 1991) acquired particular logistical, financial and administrative, banking and business characteristics largely due to its successful location in the center of the country, at the intersection of transport and trade routes, and shifted away from its original function of the industrial city. Those trends have manifested in a new altitude range from the beginning of the 21 st century to the present day. Nowadays, there are 850 buildings with the height exceeding $35 \mathrm{~m}, 40$ of which have 25 floors (more than $75 \mathrm{~m}$ ), 4 of which have 32 floors (more than $100 \mathrm{~m}$ ) and 2 of which have the height of $200 \mathrm{~m}$; Yekaterinburg ranks No. 7 in Europe and No. 3 in Russia with regard to the index of high-rise development, and in the absolute values of the altitude range in the Russian Federation it gives place to Moscow (according to the data of the Non-profit Partnership Self-regulatory Organization "Ural Builders Union" as of 2014) [11]. In 2011, a 50-story building Vysotsky (height $=188.3 \mathrm{~m}$, architect: V. Grachev) was erected in Yekaterinburg, breaking world records with regard to the height of buildings [12]; it headed towards a Guinness World Record as the highest building in the world to the north of 56 degrees north latitude; in 2016, the construction of the 52-story Iset building tower was completed; it is located in the high-rise City district (height $=212.8$ at the level of crown spikes, architect: Werner Sobek, LLC Dominanta) [13, $14,15]$. During the first decades of the 21 st century, a number of high-rise buildings were constructed in Yekaterinburg: they distinguished by innovative architecture, unique compositional and imaginative, as well as structural solutions situated within the historically developed environment. Introduction of high-rise development, in particular, into the central (historical) part of the city, still provokes an active discussion among professional architects. It is discussed whether it is worthwhile to introduce high-rise development into the structure of Yekaterinburg or switch to the traditional architecture. In 2000-2010, trends in high-rise development, using the compositional and imaginative ideas of the Urals constructivism, emerged in Yekaterinburg. Among numerous designs and implemented solutions of that period, the following can be noted: the Summit business center in the circus area (height $=93.5 \mathrm{~m}$, architect: B. Demidov, 2011), administrative building beyond the railway station (architect: V. Barantsev), high-rise retail and office building Antey-1 (height $=76 \mathrm{~m}$, architect: A. Molokov, 2004), February Revolution residential complex (height $=139.6$, architects: I. K. Ivanov, V. M. Ilyinykh, A. S. Bashkirov, 2010), Demidov Business House (height $=134 \mathrm{~m}$ (crown), designed by Arkhstroyproekt-A, 2016), partially erected complex of high-rise buildings "Yekaterinburg City", and high-rise building of the Prisma shopping mall (height $=151$, architect: Chernyshev, to be completed in 2018-2019) [6]. High-rise complexes transforming and modernizing the image of the city, such as 24-story residential buildings on Radishcheva street and a complex of 5 high-rise buildings in Khimmash (Admiralsky residential complex) were built in peripheral areas and areas distant from the center of the city. If to 
define the main direction of the high-rise development of that period, it may be said that it is in line with architectural and urban-planning innovations of Europe and the United States.

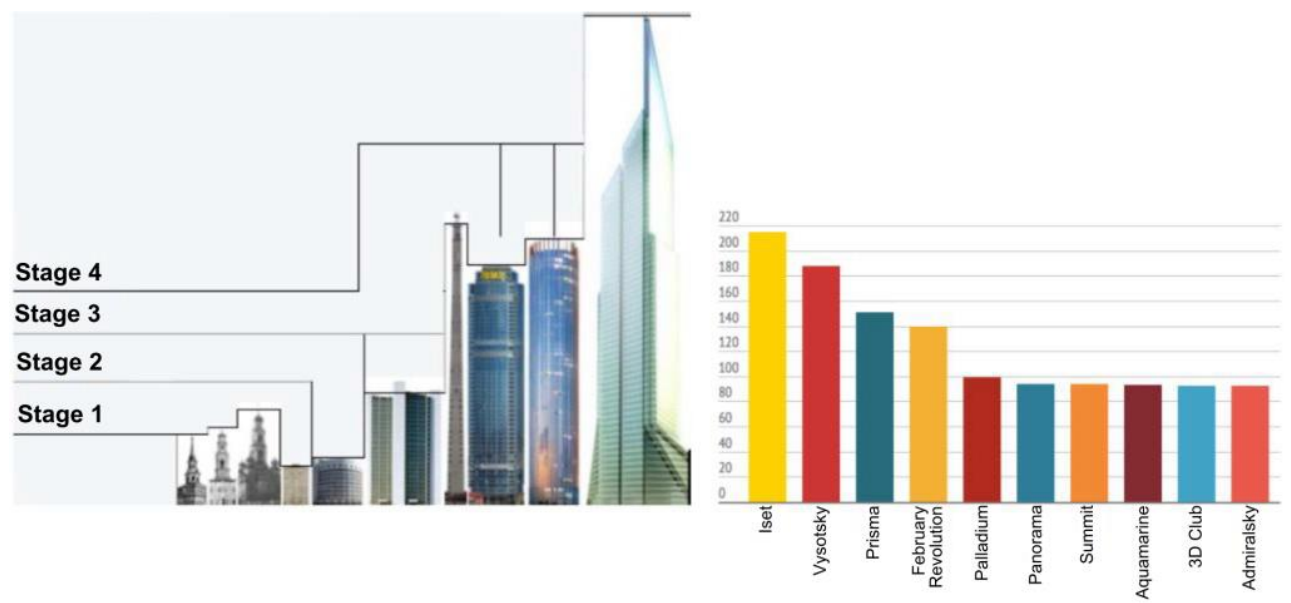

Figure 1. Historic stages of high-rise development. Altitude range diagram [16] for 10 highest modern high-rise buildings in Yekaterinburg

Taking into account the history of high-rise development in Yekaterinburg, it can be concluded that it is important to introduce buildings of excess height (rather than high-rise buildings) into the city structure; it is unlikely that super-high-rise buildings will appear in the city in the future, as they do not correspond to the large-scale structure of Yekaterinburg (as one of the most compact cities with a million-plus population in Russia) and fall out of the context of the historical part of the city (Figure 1).

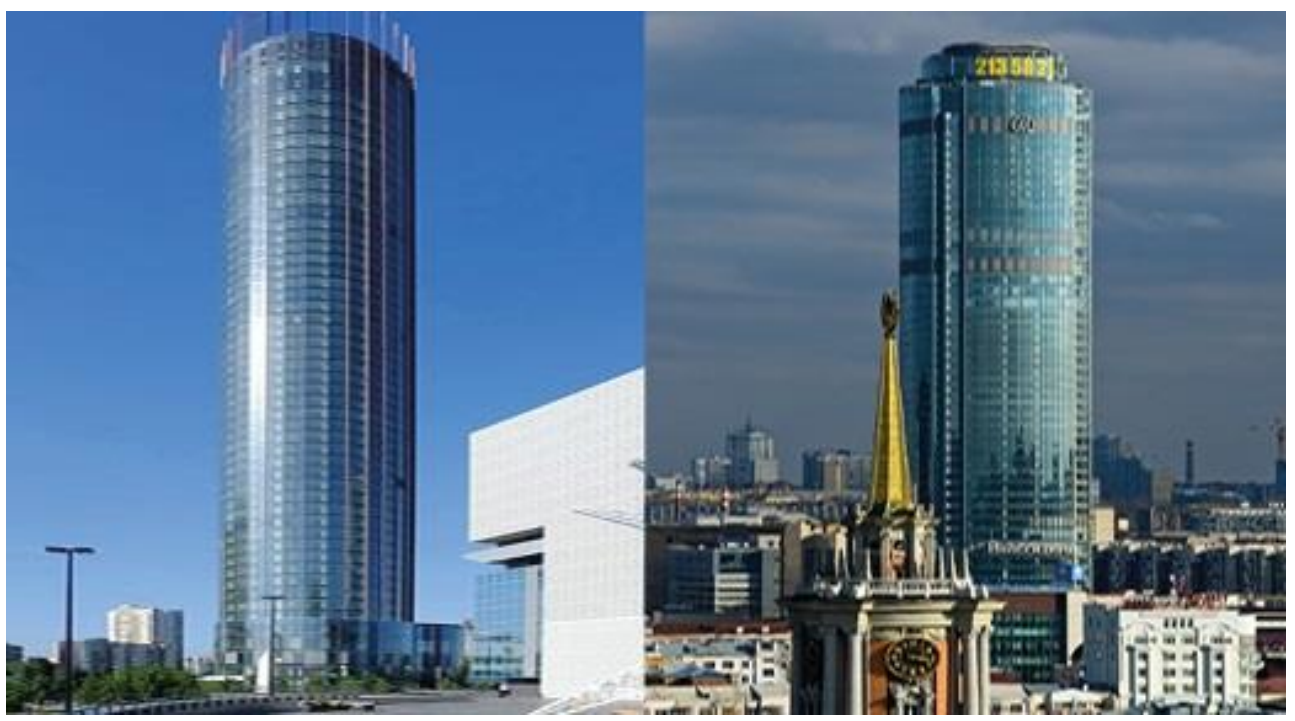

Fig. 2. Two highest skyscrapers of Yekaterinburg: the Iset Tower residential complex, overall view (left), Vysotsky business center, overall view (right) $[13,8]$

At the present time, mainly buildings of excess height with a rigid or flexible planning structure, as well as high-rise buildings-stack-like structures with a free or combined 
planning structure are erected in the city; simple vertical block atriums to arrange a part of communications spaces are used less frequently (Figure 2). Complex spatial structures with alternating vertical and horizontal atriums and autonomous enclosures are still absent in the high-rise development of Yekaterinburg. In general, complex spatial and typological structures are represented in experimental and competitive design. It can be assumed that, in the future, the high-rise development in Yekaterinburg will not head towards records with regard to the height of buildings to the north of 56 degrees north latitude, but will follow the direction of the establishment of innovative techniques for the structural organization of high-rise buildings and humanization of the internal structure of high-rise buildings.

\subsection{Promising trends in high-rise development regulation in Yekaterinburg}

Main directions for high-rise development regulation in Yekaterinburg were determined by the architectural community of the city based on the results of assessing the existing highrise buildings in Yekaterinburg, public and professional discussions and analysis of construction experience in Moscow and Saint Petersburg, as well as several European cities. Let us enlist those directions.
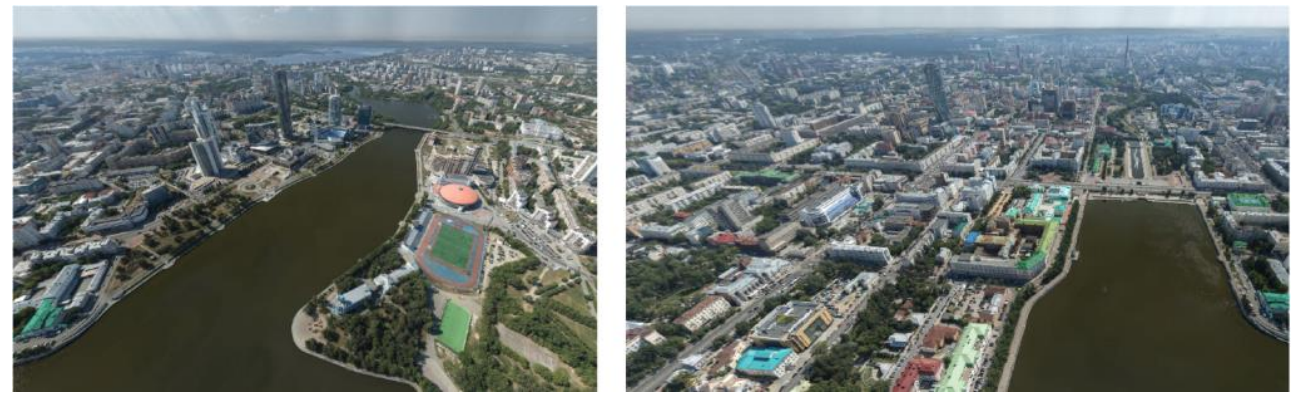

Fig. 3. Panoramas of the center of Yekaterinburg. View of the city pond (left) and dam (right) [17]

Quantitative restrictions of high-rise development. The architectural and urbanplanning practice of regulating high-rise development in Moscow gives a positive example for the introduction of temporary regulations for the limitation of high-rise development, especially in the center and historically protected area (Figure 3). The number and location of newly constructed high-rise buildings should be determined by a special plan for highrise development, approved by the city administration.

Redistribution of high-rise buildings in the city structure. The relatively high density of high-rise buildings in the center of Yekaterinburg leads to the conclusion that it is necessary to introduce certain numerical indicators limiting the introduction of high-rise buildings into the current environment, and, possibly, optimize the design of high-rise ensembles and complexes in the periphery areas that have rather good connections to the center of the city with highways.

Limitation of high-rise residential development. Large-scale construction of high-rise residential complexes is not practical as Yekaterinburg has vast undeveloped territories. One of the aspects of high-rise development in Yekaterinburg is related to the overestimated land value and the desire of developers to save expenditures on landscaping and utilities, not taking into account the cost of facility operation. The second aspect is related to the fact that high-rise residential development is treated as a sort of experiment for the establishment of a new type of the comfortable living environment.

Brand function of high-rise buildings and brand positioning of the city. The obvious competition of large and largest cities with regard to high-rise development 
produces a certain advertising effect and can affect the economic attractiveness and tourism appeal of a non-capital city. Such effect in Yekaterinburg was achieved with the help of such high-rise objects as the Vysotsky building and Iset tower.

\subsection{Creative concepts for the development of high-rise architecture in Yekaterinburg. Experimental design}

Natural, climatic and environmental peculiarities of the region impose certain limitations on approaches to design. Yekaterinburg is located in the area of moderate continental climate. It is characterized by variable weather conditions and well-marked seasons of the year. Environmental conditions are unfavorable due to the large number of heavy-industry enterprises in the territory of the Urals region. The level of pollution with industrial wastes is high.

Based on environmental, natural and climatic peculiarities of the region, main tasks of designing high-rise buildings are as follows: environmental protection and compensation for adverse environmental effects; maximum use of favorable environmental factors; compactness and wind protection; establishment of optimum micro-climate inside buildings; introduction of natural components into the structure of buildings. Based on the international $[18,19]$ and national experience in high-rise development and considering the development prospects in Yekaterinburg, we shall mention a number of creative concepts describing prospects for the possible development of high-rise architecture, as well as structural and compositional features of high-rise buildings.

The "green architecture" concept of high-rise development allows taking account of local natural and climatic peculiarities, maximum use of favorable factors, optimum energy balance of the building, and introduction of the "green component" into the structure of the building. This concept involves the use of specific spatial-planning techniques, as well as methods for integrating the natural component into the structure of the building, i.e. improvement of energy-saving characteristics of the building at the expense of its shape and orientation; methods of integrating the natural component into the structure of the building (integration of the building into the natural/man-made landscape, application of "green" enclosures and "green" vertical (with necessary fire spacing) and horizontal atriums, blockgarden systems for 3-4 floors, winter floor-by-floor gardens, landscaping of communications spaces, vertical landscaping of surfaces, "green" roofs, imitation of living nature, use of geo-plastics to form the underlying "basic" element of a high-rise building) (Figure 4) [4]. 

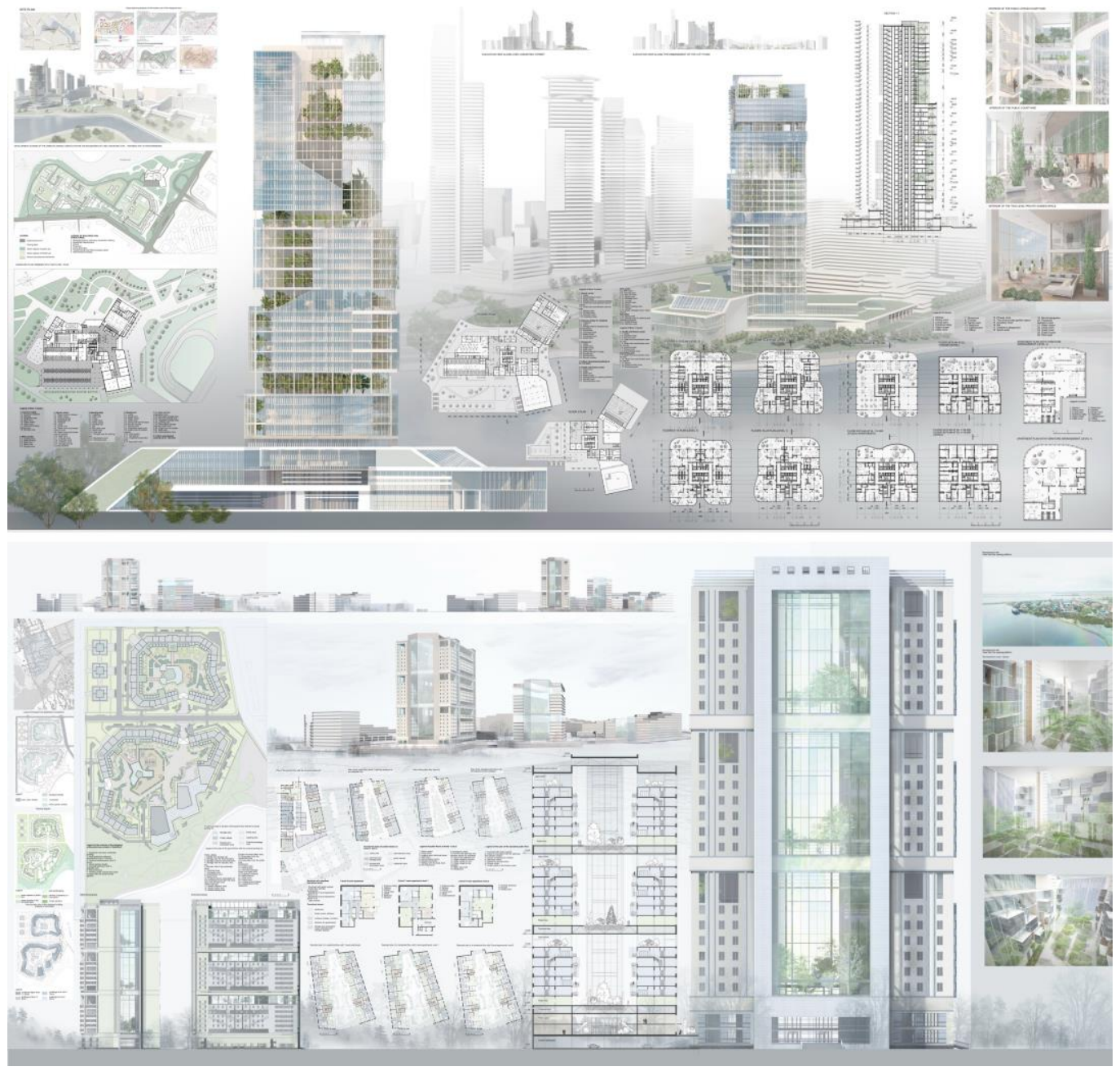

Fig. 4. Experimental designs of high-rise residential buildings with "green" atriums for Yekaterinburg. Projects of A. Shilkova (top) and D. Yarovenko (bottom), supervisor: A. V. Merenkov

"Building-enclosure" concept. The idea of this concept is to form a relatively autonomous internal spatial-planning structure and an external "enclosure" facade. Separation of the enclosure and internal structure is appropriate for modern high-rise buildings. The design principle is based on the development of an "environmental skin of the building" - an enclosure covering all interior spaces of the building (Figure 5) [4]. 


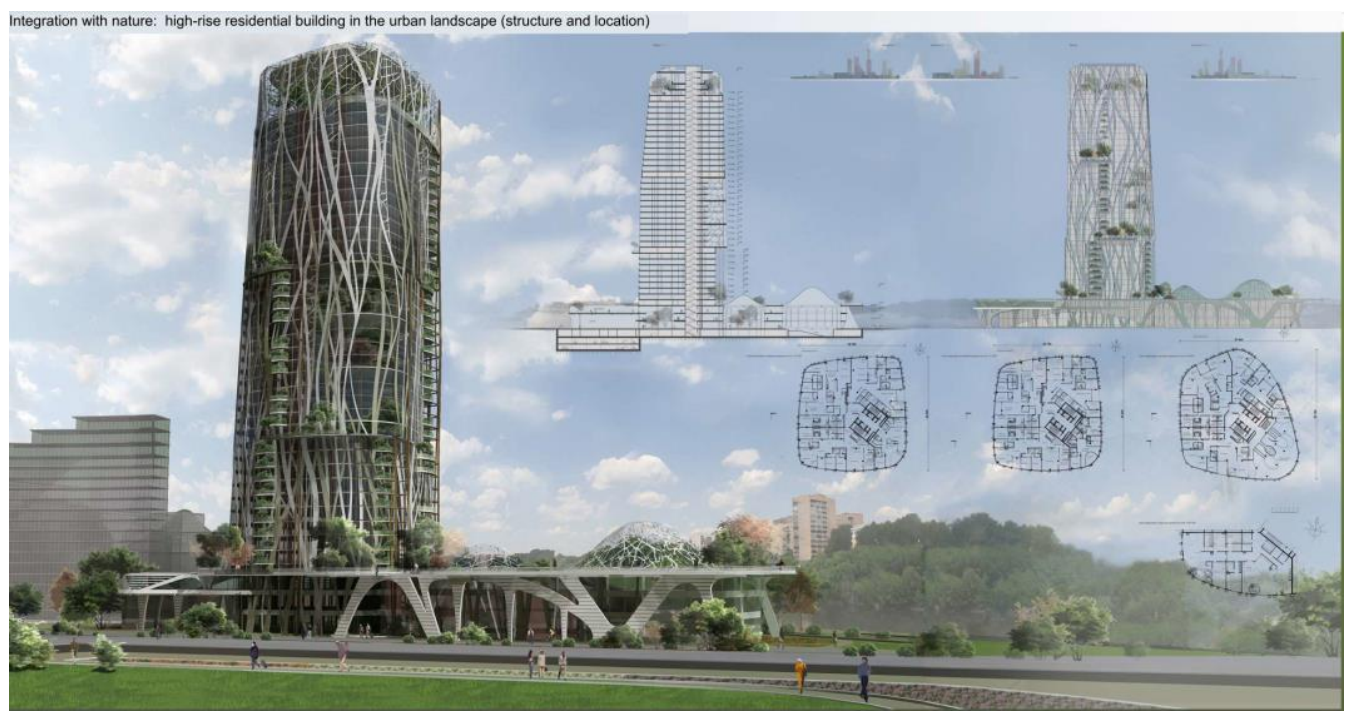

Fig. 5. Experimental design of a high-rise residential eco-building. Project of A. Grigoryeva, supervisor: A. V. Merenkov

Concept of the "architecture of information space". Its main characteristics are the following: interactivity, virtuality and adaptability. Among the methods of implementation, the following can be noted: shifting of module elements of the form in several planes; overlapping of volumetric modules and enclosures; displacements in planes; turning and changing of module proportions; deformation. Possible directions of dynamic transformations are horizontal dynamic structure of the building stylobate; centric vertical dynamic structure of the main volume; heterogeneous dynamic structure of the whole complex (Figure 6).

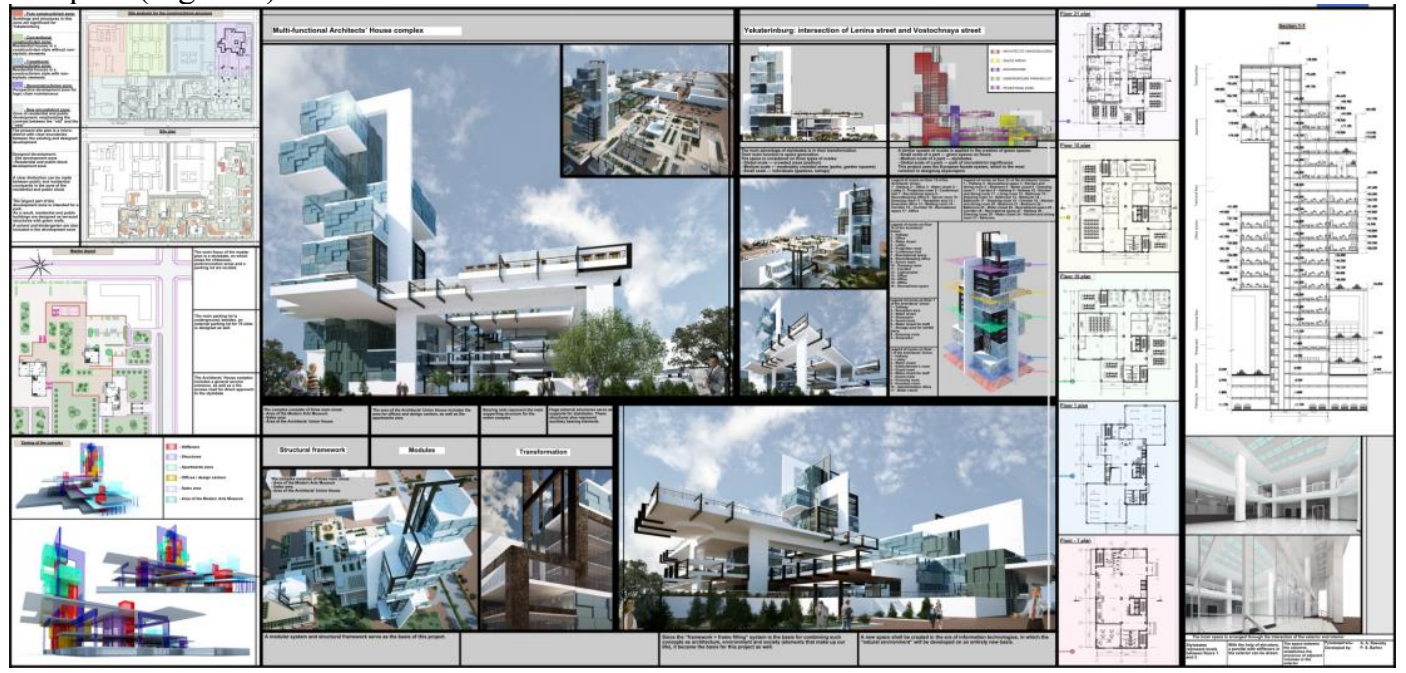

Fig. 6. Experimental design of a multi-functional complex. Project of P. Bartov, supervisor: A. A. Raevsky

Concept of "graffiti architecture". It is a modern direction in architecture, based on the use of graffiti in design. The following principles of graffiti introduction in architecture can be noted: packaging principle, veiling principle, screen (shield) principle, text-building principle. 
Examples of the transfer of planar graffiti to architecture: "classic" planar graffiti; planar graffiti with volumetric elements; photo-realistic image of the volume of a graffiti composition, "soaring" in the air; abstract geometric compositions performed in the technique of collage with three-dimensional elements in the base; graffiti sculpture; scaleless designs of architectural compositions; human-scaled urban sculpture; conceptual designs of architectural objects (Figure 7).
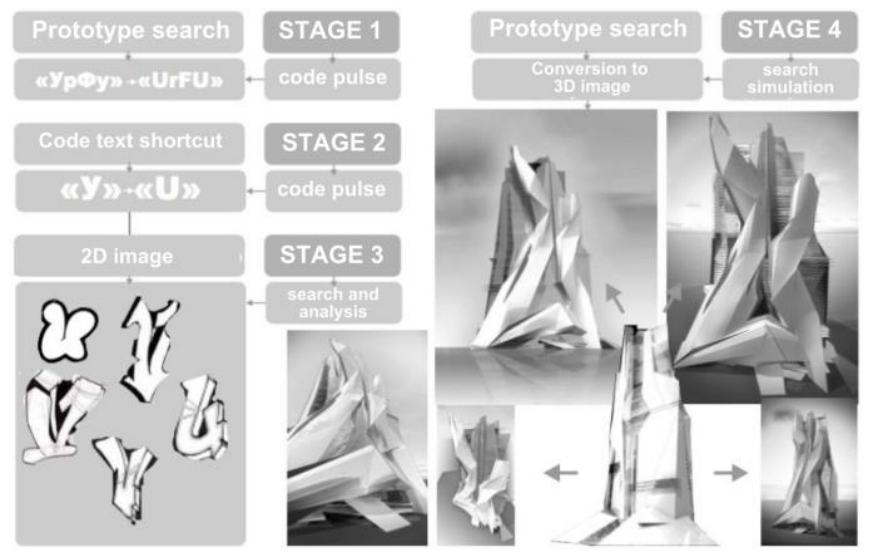

Fig. 7. Methods of shape formation in graffiti architecture. Proposed by Ye. Yevdokimova, supervisor: Yu. S. Yankovskaya

The concept of the "brand building" is especially relevant for high-rise architecture. Based on this concept, a brand building shall have the following general characteristics: awareness; uniqueness; adequate positioning (in terms of geographic location, adjacent territories, population mentality, quality of life, and time); clear and memorable image (Figure 8).

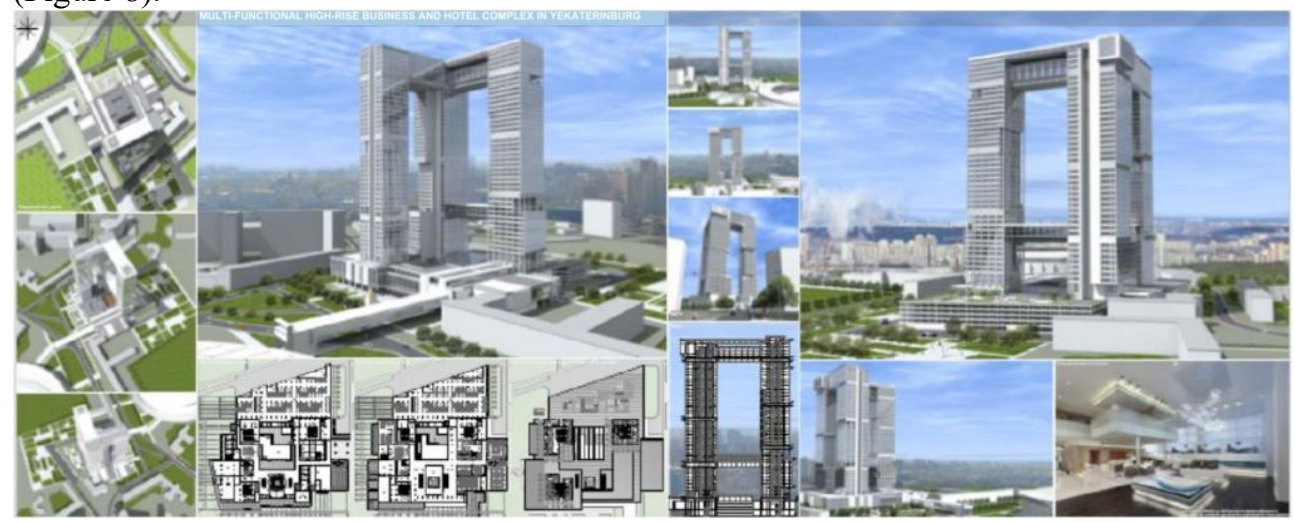

Fig. 8. Experimental design of a multi-functional high-rise business and hotel complex. Project of V. Blinov, supervisor: S. A. Dekterev

\section{Discussion}

The following should be noted among the obvious problems at the current stage of high-rise development in Yekaterinburg: debating issues of high-rise development arrangement in historically valuable areas of the city; lack of appropriate high-rise development 
regulations; low relevancy of high-rise residential development; preferences for high-rise complexes in the peripheral territories of the compact city.

At the present time, a variety of problems associated with the arrangement of high-rise buildings in the historical center and violation of the perception integrity with regard to the architectural appearance of the city need to be resolved. Let us provide the most vivid and controversial examples:

- high-rise development in the panorama of the water area of the city pond. From the city establishment until the end of the $20^{\text {th }}$ century, the city pond was perceived as a significant water area. Meanwhile, masterpieces of constructivism (UNESCO monuments) - a park of the Dinamo stadium and a "ship-house" viewed from the embankment, provided the entire ensemble with a memorable view and ensured the recognition of the city panorama. At the present time, standard high-rise development prevails in this panorama, destroying the uniqueness of the architectural picture (Figure 9).
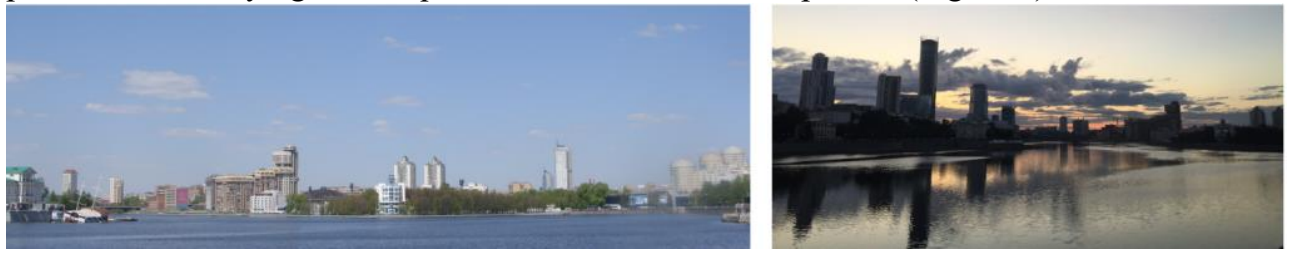

Fig. 9. Day and night views of the city pond panorama

- the building of the City Executive Committee and City Council was originally intended as a dominant on the central square of the city. The positioning of the new Palladium business center destroyed the idea of an impressive city dominant, while numerous high-rise objects completely negated the role of the building in the panorama of the city (Figure 10);
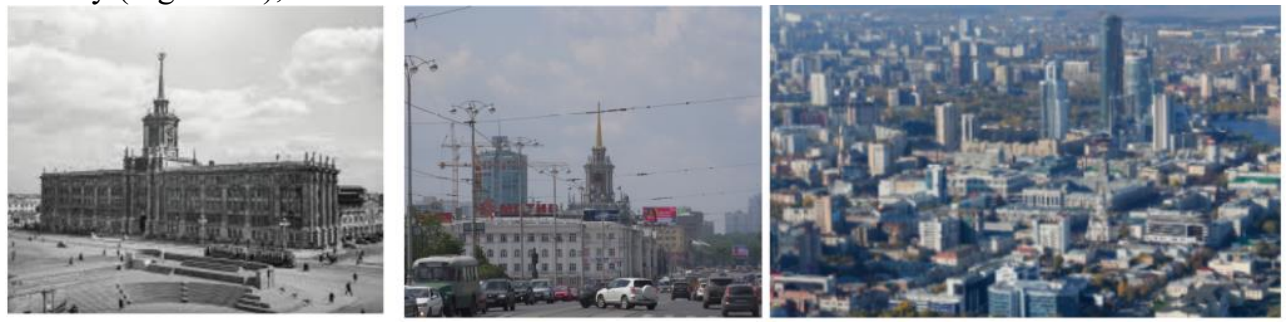

Fig. 10. Building of the City Council on the central square (left), in sight of Lenina Street (center), in the panorama of Yekaterinburg (right)

- the Vysotsky business center building in the historical center of Yekaterinburg (Figure 11)
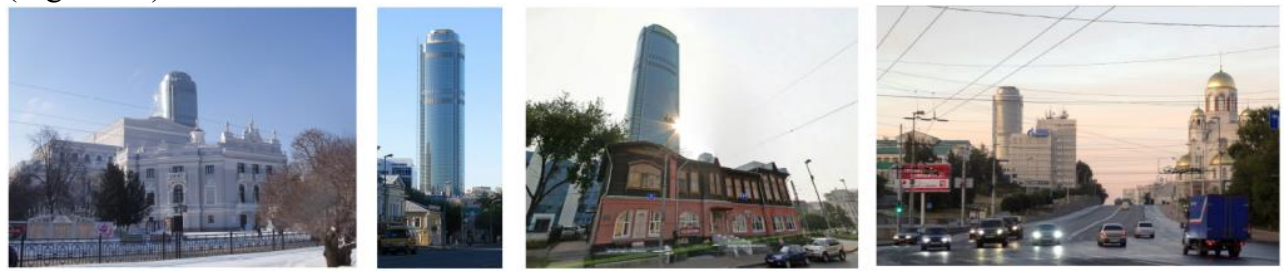

Fig. 11. Active silhouette of the Vysotsky business center in the historical center of the city

Obvious prospects of the current stage of high-rise development in Yekaterinburg include the following: creativity of young architects, a significant role of high-rise development in the city positioning, focus on the search for new structural, compositional 
and imaginative solutions for modern high-rise buildings within the framework of experimental and competitive design.

\section{Conclusions}

1. The article provides the summarized classification of high-rise buildings by two basic characteristics: by height and nature of the building structure.

2. Four main historic stages of high-rise development in Yekaterinburg are marked out. High-altitude characteristics of large-scale development changed with time up to the end of the 20th century, while the main historically developed high-rise dominants maintained their role. Activization of high-rise development occurred at the beginning of the $21 \mathrm{st}$ century and resulted in a fundamental change in the city appearance, its silhouette characteristics and panoramas. Buildings of excess height prevail at the city periphery, while high-rise development prevails in the center. At the same time, as a rule, most of the constructed high-rise buildings do not have a complex spatial structure. Architectural and spatial, typological and engineering experiments are presented mainly in the field of experimental and competitive design.

3. Complex natural and climatic peculiarities, on the one hand, limit architectural experiments, and, on the other hand, give it a new interpretation within the search for innovative architectural solutions in experimental and competitive design.

4. The application of the global experience in high-rise and super-high-rise development in Yekaterinburg revealed both promising and negative aspects in the formation of a modern urban environment. In particular, this is the case of the compatibility of high-rise dominants and traditional, historically significant objects, perspectives and panoramic views.

5. Prospective directions of high-rise development in Yekaterinburg were defined: introduction of regulations for high-rise development in the city center; activization of high-rise development in the peripheral areas; the search for brand high-rise architecture requires the development of new forms and structures based on the specifics of the region and experience in experimental and competitive design.

\section{References}

1. http://www.usaaa.ru/faculties/fa/issuing/arhitektury/vysotnoe-zdani 12.12.2017

2. http://www.usaaa.ru/faculties/fa/issuing/arhitektury/mfzhk 12.12.2017

3. http://www.usaaa.ru/faculties/fa/issuing/arhitektury/diplom 12.12.2017

4. http://www.usaaa.ru/faculties/fa/issuing 12.12.2017

5. E. M Generalova, V. P Generalov, A. A. Kuznetsova. Cantilever Structure in Modern Construction. MATEC Web of Conferences. Editors: S. Jemioło, A. Zbiciak, M. Mitew-Czajewska, M. Krzemiński and M. Gajewski. 00057 (2017)

6. A. Radford, S. B. Moroc, A. Strivastava. The Elements of Modern Architecture. Understanding Contemporary Buildings, L.: Thames \& Hadson (2014)

7. E. M Generalova, V. P Generalov, A. A. Kuznetsova. Innovative Solutions for Building Envelopes of Bioclimatical High-rise Buildings. Environment. Technology. Resources Proceedings of the 11th International Scientific and Practical Conference. 103-108 (2017)

8. C. G. Crysler, St. Cairns, H. Heynen (ed.). The SAGE Handbook of Architectural Theory. L.: SAGE Publication Ltd, 41-56 (2012)

9. A. Yudina. Garden City. Supergreen Buildings, Urban Skyscapes and the New Planted Space, L.: Thames \& Hadson (2017) 
10. https://ru.wikipedia.org/wiki/Список_cамых_высоких_зданий_Екатеринбурга $\underline{10.12 .2017}$

11. https://rg.ru/2014/07/08/ekaterinburg.html 12.12.2017

12. http://www.skyscrapercity.com/showthread.php?t=412073\&page $=31611.12 .2017$

13. http://www.skyscrapercity.com/showthread.php?t=526298\&page=270 12.12 .2017

14. https://ru.wikipedia.org/wiki/Башня_«Исеть»12.12.2017

15. http://img-fotki.yandex.ru/get/6712/126273919.11/0 98ed1_f8d387f1_orig 11.12.2017

16. http://ngzt.ru/news/view/02-03-2015-samye-vysokie-zdaniya-ekaterinburga-foto-videomultimedia 12.12.2017

17. https://екатеринбург.рф/жителям/город/панорама 10.12.2017

18. H. Plammer. The Experience of Architecture, L.: Thames \& Hadson 7-27, 84-103 (2016)

19. A. Betsky. Architecture Matters, L.: Thames \& Hadson (2017) 